\title{
ROMANIAN TERRITORIAL CLAIMS DURING WORLD WAR I UNDER THE GAZE OF THE RUSSIAN PRESS
}

\author{
Andrei EMILCIUC \\ Institute of History, Chişinău, REPUBLIC OF MOLDOVA \\ emilan@live.com \\ DOI: http://doi.org/10.23740/TID220201
}

\section{ABSTRACT}

The article analyses the approach of the Russian press towards the Romanian territorial claims during the World War I. It is ascertained that the territorial issue was important in Romania's attitude towards war, as the unification of historical and ethnic Romanian territories was essential for the national affirmation of Romania as a state. In this regard, the Russian press pointed towards the territories under the rule of the Austro-Hungarian Empire as a major priority for the formation of Greater Romania. The goal was to attract Romania on its side against Austro-Hungaria $n$ and German offensive on the Eastern front. We scrutinize the Russian press's approach towards Romanian territorial claims based on three distinct periods: 1) during Romania's neutrality; 2) during Romania's participation in the war as Russia's ally; 3) After the Bolshevik revolution, when Russia withdrew unilaterally from the war. The emphasis on Romania's territorial claims is shown mostly in the first period, with one exception - the Bessarabian issue is little or not mentioned at all. Within the second period, the Russian press almost lost sight of the Romanian territorial claims. Finally, the Bolsheviks, who proclaimed self-determination as the main approach to territorial issues, were those who denied Romania any claim for "disputable territories", just because it opposed Bolshevization. During this latter period, the Bessarabian issue becomes the spear of Russian informational attacks against Romania, following the Union of this historical Moldavian territory with the Motherland.

Keywords: World Warl, Russian propaganda, Russian state-run press, Romanian historical territories, RussianRomanian diplomatic relations

Cite this articleas: Emilciuc, A. (2020). Romanian Territorial Claims during World War I under the Gaze of the Russian Press. Territorial Identity and Development, 5(2), 7-26. DOl: http://doi.org/10.23740/TID220201

\section{INTRODUCTION}

World War I broke out when territorial disputes in the modern era had reached their peak. The great modern empires, whose essence was based on an expansionist economic system, hit the possible limits of annexationism without risking to provoke a major confrontation. This was due to the formation of the two rival pan-European military blocs. Throughout this equation, an increasingly key role is played by the nation states, which appeared during the $19^{\text {th }}$ century, and were eager to defend their borders, but also to adjust them based on historical and ethnic principles, at the expense of the territories under foreign domination.

In this respect, on the one hand, for the modern Romanian state, formed by the union of the two medieval Danube Principalities of Moldova and Wallachia in 1859, the priorities of national assertion acquired rapidly a well-founded ideology with both historical and ethnical 
arguments. The first lost were Bukovina and Bessarabia, because of the annexation of the former by the Habsburg Empire in 1775 and of the latter by the Russian Empire in 1812. Both were previously part of the medieval Moldavian territory and, despite an intense policy of denationalization, the Romanian population had maintained an important ethnic share.

On the other hand, there were two more territories, Transylvania and Banat, which although were not part of the Romanian medieval state, but by virtue of substantial Romanian population, also occupied an essential place in the national idea of the Romanian state, of which the moment of the "Union" accomplished by Mihai Viteazul in 1600 was placed on the frontispiece. In the given European geopolitical context, Romania was required to make a political choice in favour of one of the two military blocs created in Europe, in order to hope for at least a partial materialization of its national ideal. The choice was made considering the experience of participation with Russia in the anti-Ottoman war of 1877-1878.

Despite the common victory, with significant human losses, Romania sees the three counties in southern Bessarabia, the territory of which was regained as a result of the Paris Peace Treaty of 1856, taken back by Russia. Instead, it was offered the territory of Northern Dobrudja, which backed outrage from the newly formed modern Bulgarian state, as this territory was seen by the latter as part of its ideal nation-state. The Dobrudja issue will lead to a direct confrontation with Bulgaria in the Second Balkan War (1913), in which, fearing of the possible emergence of a large and strong Bulgaria on its Southern borders and possible territorial claims towards Northern Dobrudja, Romania also intervened militarily against Bulgaria. By this time, by virtue of the objective necessity to have a direct access to the sea, Dobrudja had already been integrated into the national concept of the unitary Romanian state, with both historical (the Vlach-Bulgarian Kingdom from the $12^{\text {th }}-13^{\text {th }}$ centuries) and ethnic arguments (due to the active Romanian population after 1878). The annexation of southern Dobrudja to the Kingdom of Romania, as a result of the Peace Treaty of Bucharest (1913), would definitely worsen the relationship with Bulgaria. Thus, the outbreak of the First World War found Romania surrounded by real, not conjuncture enemies, from both rival camps, which represented a real challenge for the political class of the country.

Accordingly, the decision of the Crown Council, taken at Peleş Castle in Sinaia on July 21 / August 3, 1914, to maintain Romania's neutrality, seems logical. Firstly, it did not allow the transformation of Romania into a military theatre for no clear gain, and secondly, there was no clear ally that it could trust. The change could only come with precise assurances regarding the post-war fate of the territories populated by the Romanians outside Romania's borders and, in concrete terms, their entry as widely as possible under its authority.

The countries of the Entente, but also those of the Central Powers launched a diplomatic campaign to attract it on their side, obviously the negotiations being made at the expense of the enemy, which would eventually be defeated. The details of this diplomatic game were kept mostly away from the masses. The press in the concerned states, however, occasionally revealed, more or less veiled, the events occurring in the background. Often, it took the form of monologues compared to the voiceless opponent. But the analysis of these press materials reveals very eloquently the essence of these territorial disputes. And, as the relationship between Romania and Russia during the First World War was perhaps one of the most oscillating, we find it even more intriguing how the Russian public opinion was informed on the Romanian territorial claims, following the political relationship between the two states. 


\section{THEORETICAL BACKGROUND}

In addressing the proposed topic, it is necessary to note that during the war the official staterun press increases its propaganda mission, in order to convince its own citizens, existing and eventual allies, in the firm unity of its people, and the strength and legitimacy of its military actions, on the one hand, and on the military weakness and the atrocities of the enemy, on the other. A decisive role in the management of propaganda in the Russian Empire during the war was played by the Information Bureau of the General Directorate of Press and Printing. This institution worked closely with the Petrograd Telegraph Agency, the Office of Russian Journalists, and other news agencies, press commissions, and also private publications (Волковский, 2003, р. 108).

It is worth mentioning that the staff of the Russian Information Bureau carried out extensive analysis of both the Russian and foreign periodicals - from allied, neutral and hostile states (Волковский, 2003, p. 108). It is true that such offices also operated in other European countries, including Romania (Spânu, 2012). That is why it is necessary to be aware that certain materials distributed by the Russian Information Bureau to the press could target not only the internal public, but also the "external" one, in other words the press represented an informal diplomatic communication channel. We would like to point out that the Information Bureau under the Russian Army General Headquarters had special funds to subsidize printed publications, both in Russia and abroad, in close cooperation with the Russian government. In this way, the Information Bureau sought to strengthen its influence on public opinion inside and outside the Empire, especially in neutral states. Various articles, prepared in advance by the Bureau's employees, were sent to numerous journalists, including from Romania, who "cooperated" with the institution (Волковский, 2003, pp. 108-109). Subsequently, materials placed in this way in the foreign press were quoted on the pages of the Russian press, in order to extend the desired effect already on their own reading public.

The Russian-Romanian relations during the First World War aroused great historiographical interest in both countries, and even beyond them. Most of these works focus on the contradictory issues between the two states, like the issue of Bessarabia, and that of the Romanian Treasure refund, and bear a hostile approach towards the other side even on less painful issues. Our main goal is not reviewing or per se citing the opinions expressed in these works, as the extent of this article is limited. In our opinion, it is eloquent to show the reader how the Russian approach towards Romanian territorial claims changed during the war. The Great War put an end to the Empires of Modern Era, for which the territorial annexes were the right of the strongest, replacing it with a new ideology based on historical and ethnical arguments. However, it is worth noticing that in former metropoles this ideology was adapted to justify the right of extension within the ante-war imperial borders.

\section{METHODOLOGY}

The study of the given topic follows the general methodology and principles of the historical research. First, the selection of sources was performed by a general overview of the official Russian newspapers published during the war, and the identification of the issues which reflected the proposed topic regularly. We found that the territorial claims of different states were analysed especially by the press dealing with military topics or affiliation. This is not something odd, as the militaries from the front lines required a "better understanding" of the 
purposes they were fighting for, but also of those belonging to their allies and enemies. As propagandist leaflets were often used at the front lines, the official military press had also the aim of annihilating the enemy's propaganda by own propaganda. Secondly, for a clear understanding of the newspapers' articles and materials, we used secondary sources, papers and works of Romanian and Russian historians who revealed and analysed historical facts, based on archival and published documents. Thus, we were able to face facts and events, and identify hidden causes and goals using chronological principles and phases of the Romanian participation in the Great War, and of its relationship with Russia.

In this regard, please notice that the Julian calendar was in use in Russia until February 1, 1918 and in Romania up to April 1, 1919. Thus, if in the case of newspapers we provided the date on the frontispiece, forvarious international events and treaties we provided the date according to both calendar styles, Gregorian and Julian, separated by "/", in order to avoid confusions. The difference between these two calendars gathered 12 days in the $19^{\text {th }}$ century, and 13 days in the $20^{\text {th }}$ century.

\section{RESULTS AND DISCUSSION}

\section{Russian press on the territorial claims of Romania during the period of its neutrality}

The issue of Transylvania, completed shortly after that with the issue of Bukovina, will be "exploited" with reference to Romania since the first months of the war, especially by the Russian military press. In fact, on September 18 / October 1, 1914, Russia will sign a secret agreement with Romania in St. Petersburg, which officially recognized the latter the right to reunite parts of Austria-Hungary inhabited by Romanians, including Bukovina, being established that the principle of nationalities should serve as a basis for delimiting territories (Istoria, 1989, p. 340).

On the other hand, the danger of Bulgaria entering the war against it, determined Russia to lure it with a possible haggling, by which Romania would cede Dobrudja in exchange for Transylvania. At least this is clear from the article of September 26,1914, signed by the retired general N. Butovski, who, with the outbreak of the Great War, was involved in several commissions of the Russian Army General headquarters. Thus, his opinion can be cate gorized as representing the position of the Russian military leadership circles, especially since the article is placed on the pages of the official press organ of the Russian Army General Headquarters. Regarding Romania, the author claims that this has only one chance to become a great European power, but this chance can always vanish and that "Maybe Romania is af raid that by occupying Transylvania, it will provoke the Bulgarian armies towards Dobrudja? What a big deal! The map of the future Europe will be drawn by a great coalition, which will dictate its will in Berlin". Apparently, such a statement can be understood as a direct threat to Bulgaria, in the sense of the possibility of Romania's return to Dobrudja after the war, and therefore the futility of Bulgaria's entry into the war. However, the article reveals a peaceful attitude towards Bulgaria. As the author also states here, despite Bulgaria's aid to the Germans in transporting weapons to Turkey, "Russia still loves it, like a mother does her lost daughter" (Русский Инвалид, 1914, No. 212, p. 3). In this respect, the above phrase would sound more like an assurance to Bulgaria about a positive solution to Dobrudja's issue for the Bulgarians, in exchange for maintaining neutrality, or for entering the war on the Entente's side. 
Since the very beginning of the war, the Russian military press had also reported in detail all the actions of the Romanian pro-Entente camp and offered its own justification why Ro mania had to enter the war and liberate Transylvania. An editorial technique that was used frequently would be the citation of the appropriate materials from the Romanian press. The press organs of the conservative-democrats led by Take Ionesco - "Acţiunea" (January 31, 1913 - November 14, 1916), "Evenimentul” (November 14, 1916 - December 1, 1918), the newspapers "Adevărul", "Universul", "Roumanie" and others that promoted the idea that Romania shall enter the war on the side of France and her allies, in order to liberate the territories populated by Romanians under the domination of the Austro-Hungarian Empire were preferred. Also, the harsh criticism of Austria-Hungary, but also of its ally - Germany, placed on the pages of these newspapers, suited Russian publishers perfectly. The citation of the materials from the Romanian press was intended to be a solid argument of the fact that the presented ideas were not just subjective opinions expressed by the Russian editorialists. On the other hand, the Russian press completely ignored the press of the opposite camp, the newspapers of the conservatives Alexandru Marghiloman, Titu Maiorescu, Theodor Rosetti, Petru Carp, Virgil Arion, Dimitrie S. Neniţescu and others, who supported Romania's joining of the Central Powers to stop the Russian expansion in the Eastern Europe, having the conviction that Bessarabia could be liberated from the Russians. The press of the Romanian liberal governing party was of no real use for the Russian press, as it was too "neutral" for the propaganda purposes.

Thus, based on information from Romanian press, about the large demonstration that took place in Bucharest on November 25 / November 7, 1914, in front of the monument of Mihai Viteazul, the October 26, 1914 issue of the Russian Invalid newspaper reported that the eve nt was attended by thousands of citizens and students, who gave patriotic speeches, urging the achievement of national goals and union with the Romanians in Transylvania and Bukovina. Participants later went to the house of former Minister of War NicolaeFilipescu, who delivered a speech, claiming that Romania "must enter now into war to save the Transylvanian Romanians, with the support of Russia, because after the end of the war, if Austria will be among the winners, it will surely destroy the Romanianness in Transylvania, and then we will have to go to war against them on our own" (Русский Инвалид, 1914, No. 241, p. 3). The same newspaper wrote on November 1, 1914 that:

\footnotetext{
"The gap between the government and the unanimous goal of the people is being felt more and more strongly, demanding to immediately make a stand against Austria for the liberation of the Transylvanian and Bukovina Romanians from the Austrian yoke. In response to the fervent manifestations of the people and the youth, Brătianu's cabinet threatens to place Romania under curfew [...] The popular newspaper Adevărul wonders if Brătianu is a short-sighted politician or a traitor." (Русский Инвалид, 1914, No. 247, р. 3)
}

We consider that the information in question was at that time mainly for domestic consumption, intended to strengthen the belief of the own militaries in the imminent entry of the Romanian army on the side of the Entente and thus alleviate the military burden and the certainty of victory against the enemy. In the same way, the official press organ of the Russian Army General Headquarters would report, it is true a little later, about the visit of a group of Romanian MPs to Rome in December 1914, to discuss the joint entry into the war against Austria-Hungary. It is stated that although it was the second of its kind visit to Italian capital, it "takes place in a different context, because it coincides with the intensification of the repressions of the Austro-Hungarian government in Transylvania and Bukovina, which undoubtedly raised the warrior spirit of the Romanian people" (Русский Инвалид, 1914, No. 280, p. 3). 
The year 1915 will bring more and more political materials about Romania on the pages of the Russian press, in which the emphasis will be mainly on the issue of Transylvania. Numerous materials are published informing about the political actions and pro-Entente manifestations in Bucharest and Iaşi. Also, the calls from the Romanian press in support of Romania's entry into the war as soon as possible, for the liberation of the Transylvanian Romanians from the Austro-Hungarian yoke, are cited more and more frequently. Thus, the January 28, 1915 is sue of the Messenger of the 10th Army informed readers about Romanian newspapers' reports that Transylvanian refugees were organizing a Transylvanian Legion to participate in the liberation of Transylvania along with the Romanian army, and that their number reached 5,000 (Вестник, 1915, No. 87, p. 1). On the same note, the newspaper of Petrograd Military District, reported on January 31,1915, about the fact that in Transylvania a conspiracy was revealed among the Romanian military, who had brochures stating that their brothers over the Carpathians would like to liberate them (Солдатский, 1915, No. 43, p. 2). The same newspaper reported in the February 7, 1915 issue on the circular note given to the neutral states by the Austro-Hungarian government, which stipulated that the armies fighting the Russians had been ordered to shoot all natives of Transylvania and Bukovina who had volunteered into the tsarist army (Солдатский, 1915, No. 45, p. 2).

Instead, the issue of Bessarabia is tactfully omitted during this period, and when it is addressed, it would be due to the need for an official reply. Thus, an opportunity to provoke Russia on the Bessarabia matter was achieved by an article in the Swedish press about Romania's role in the anti-Ottoman campaign of 1877-1878 and the re-annexation of southern Bessarabia to the Russian Empire. The February 4, 1915 issue of the Russian Invalid declared the article outrageously deceitful, and the description of Romania's role as extremely biased. On February 6, 1915, the same newspaper made a foray into the articles placed on the pages of the The Historical Messenger magazine in January 1915. The emphasis was placed on the memos signed by the Russian diplomat N.P. Ignatiev (1832-1908), who participated in both negotiations at the Paris Peace Conference of 1856 and the San Stefano Conference (1878). His statement that "he wanted to reach a preliminary agreement with Romania on the issue of Bessarabia", the return of which was claimed by Russia, "but all this was escaped; through the Berlin Congress we were defeated by the Germans" (Русский Инвалид, 1915, No. 29, p. 3), is highlighted. It is thus obvious that the Russian military officials considered that the antiRussian attitudes which existed in the Romanian society were related only to the issue of the three counties repeatedly torn from Romania in 1878, and not to the issue of the whole territory between the Prut and the Dniester. A significant decrease in the Bessarabian issue was thus achieved by silence and the shift of accents.

But inside Russia, there were voices that betrayed not exactly sincere games regarding the territories inhabited by the Romanians. Lieutenant General F. Vebel, the commander of the Russian army corps, which at the end of 1914 had occupied almost all of Bukovina, proposed in mid-January 1915, by a secret letter, a plan to annex Bukovina to the Russian Empire. Although the conditions of the Romanian-Russian secret agreement were known to him, F. Vebel insisted on this choice considering that drawing the border to divide Bukovina in two was very difficult to achieve, because "a mixture of ethnicities" (Ungureanu, 2014, pp. 126-127) was living in the south of Bukovina. However, the officials from Petrograd would not officially embrace this proposal, continuing to claim only the "Russian" Bukovina, without specifying the concrete borders, in order not to affect the relationship with Romania. Also, the mainten ance of the old position, in accordance with the Romanian-Russian agreement, will be "demand ed" by the Russian press. The newspaper Russian Invalid would inform in one of its issues that within the State Duma, MP E.P. Kovalevsky, a member of the Progressive Bloc, referred to 
Russia's war and its aims. The editors wanted to highlight his words, according to which only "Red Ruthenia, Russian Bukovina and Hungarian Russia must be permanently annexed to Russia" (Русский Инвалид, 1915, No. 25, р. 2).

Instead, addressing the issue of Transylvania, the Russian military press will seek to further promote the idea that it is existential for Romanians. The February 28, 1915 issue of the newspaper Messenger of the 10th Army reported about the audience granted by the Romanian king and the crown prince to the Transylvanian priest Lucaciu. Referring to the Petrograd Telegraph Agency, the newspaper emphasized that the king was extremely merciful, and the discussions were of major importance for all Romanians (Вестник, 1915, No. 113, p. 2). The same periodical informed the readers on March 10, 1915 about the rally of the Transylvanian Romanians in Bucharest, organized at the initiative of professor Mândrescu, a native of Transylvania. According to the newspaper, the assembly sent a telegram to the king, stating that "the desire to unite under one sceptre has taken such deep roots among us that its failure would be like death". The demonstrators demanded the urgent issuance of a decree to advance the Romanian army for the liberation of the Transylvanian Romanians. Another telegram was sent to Prime Minister Brătianu also requesting the urgent liberation of the Transylvanian fellows, and their salvation from complete extermination: "Your father was the founding father of today's Romania, be the founding father of the Greater Romania" (Вестник, 1915, No.130, p. 2). On March 19, 1915, the mentioned newspaper informed about the similar rally organized in laşi by the League of the Union of All Romanians. It was stated that, during a patriotic speech, the former Minister of War Nicolae Filipescu declared the following:

"In some circles the problem of Bessarabia is now raised, but so far they have not mentioned this matter, launching it only after the actions to regain Transylvania were started. We have to occupy Transylvania, because it is the centre and the heart of Romanianism, and on the tops of the Carpathians the national consciousness has found shelter. There is only one word for us Transylvania and only Transylvania." (Вестник, 1915, No. 132, p. 2)

The problem of Bukovina was also kept alive on the Romanian agenda in the Russian press, but more in a complimentary way. The March 19, 1915 issue of Russian Invalid reported on the resolution of the All Romanians' Rally, signed at Nicolae lorga's proposal, condemning "bastards who receive money from foreign corrupters in order to bring discord to their minds, and binds them forever to the pillar of shame with those who at this moment happily clink glasses on the poor Bukovina land with Colonel Fischer, the main organizer of the hanging of the Romanians from Bukovina". The resolution, which supported the entry into the war for the reunification of the Romanian lands, was addressed to the king and the prime minister (Русский Инвалид, 1915, No. 64, р. 3). The same information can be found in the pages of the newspaper Messenger of the 10th Army, which on April 20, 1915 apprised its readers, based on the information gathered from Romania, that in the event of Italy's entry into the war, Brătianu's government would be dismissed, and "the new government would then claim Bukovina and Transylvania from Austria, and in case of refusal they will declare war to it" (Вестник, 1915, No. 164, р. 2).

As Romania hesitated to follow the example of Italy, a series of reproaches against the Romanian government appeared in the Russian press. The newspaper Our Messenger published the article The Double Game of Romania. Romania was accused of continuing to bargain with the warring parties, waiting for the right moment:

"It set the price for the Allies of the Entente for which its contribution in the war against Austria can be bought. Due to existing context, the price has increased significantly; the Romanian government now claims not only Transylvania and the Romanian part of Bukovina, but also the 
Russian Bukovina with Chernivtsi and Banat, with its predominantly Serbian population. Dissatisfied with these, as the correspondent of the Kiev newspaper informs, it throws the fishing rod in London and Paris in order to correct the borders of Bessarabia, even if it does not have the courage to raise this question in Petrograd." (Наш вестник, 1915, No. 22, pp. 4-5)

In conclusion, the material is warning that by "freeing from all the obligations of the agreement with Italy", Romania can very easily wake up "with broken pots". A similar material can be found in the pages of the 10th Army's newspaper of May 18, 1915. The author informs about the rejection of Romania's territorial claims by the Allies, and highlights the Austrians' proposal to Romania to cede its three districts in Bukovina and to revise common Transylvanian border, only to maintain her neutrality (Вестник, 1915, №. 192, р. 2).

In order to emphasize the conviction that the Romanians really wanted to enter the war on the part of the Entente, the June 4th, 1915 issue of the Russian Invalid approves the call of the Romanian newspaper Adevărul of May 13, 1915 that Romanians "must go out against Austria and Germany as the honour and justice demands" and "fight against Austria, because this is the only means of making Greater Romania" (Русский Инвалид, 1915, No. 111, p. 2). In the June 10th, 1915 issue, the same newspaper shares an article of the newspaper Roumanie, entitled "God bless Italy":

\begin{abstract}
"The dice have been rolled; if we could neither make it before Italy, nor to take the sword out of scabbard together with it, we shall soon follow it. Remaining neutral does not honour us. To shout Long live Italy! means to shout Long live the war on the side of Italy! Austria-Hungary is a common enemy not only because it keeps hundreds of thousands of Italians under its domination, for whose liberation Italy has begun to fight, while millions of Romanians are still waiting. Along with these peoples, the whole world needs to be liberated." (Русский Инвалид, 1915, No. 115, p. 2)
\end{abstract}

The activity of the organizations that opted for Romania's entry into the war for the libe ration of Transylvania is followed more and more closely in the next period. Detailed information on the speeches and resolutions adopted at their meetings is presented. The June 27, 1915 is sue of the newspaper Our Messenger, informed about the invitation issued by the organizations that militated for Romania's entry into the war on the part of the Entente, to participate on June 28 at the national congress. The appeal stated that the time has come for Romania to choose either to remain an unimportant state, or to form Greater Romania, by uniting with Transylvania (Наш вестник, 1915, No. 38, pp. 4-5). The 10th Army's newspaper also reported on the rally in question (Вестник, 1915, №. 231, р. 2).

Meanwhile, at the negotiating table, Romania also brought into discussion the Banat issue. The difficult situation generated by the Austro-German offensive has led Russia to accept certain compromises. The August 4, 1915 edition of the Northwest Front Army Command's newspaper announced on its pages that "all the difficulties concerning Banat and Bukovina have been eliminated, and Romania's joining the Quadruple Agreement is considered practically decided" (Наш вестник, 1915, No. 53, p. 3), while the September 10 issue emphasized this matter by quoting General Grigorie Crăiniceanu's words for the Romanian newspaper "Universul”:

"The country has firmly decided that war with Hungary is necessary in the name of the liberation of our brothers from Banat, Bukovina and Transylvania. We will fight to the last to get these territories." (Наш вестник, 1915, No. 68, p. 4)

Even if Romania hesitated to enter the war at that moment, the Russian military press will continue to quote the Romanian newspapers articles that claimed the moment is near and blamed Romanian rulers for the delay. On the pages of the October $3^{\text {rd }}$ issue of Ourmessenger, an article, signed with the initials A.P., states that "the Romanian people have been rushing to save their enslaved brothers from Transylvania for more than a year", but all in vain, because: 
"Wilhelm sends a threat to his relative that he would deprive him of the crown if he dares to betray the interests of the Hohenzollern dynasty. The threat is taking effect, and the cart is still in place." (Наш вестник, 1915, No. 78, p. 5)

In the context of Romania's gradual rapprochement to the Entente, on October 15, 1915 the Kingdom of Bulgaria entered the First World War on the part of the Central Powers, after Germany promised to restore her borders drawn by the Treaty of San Stefano, including Southern Dobrogea (the so-called Quadrilateral). But, in the event of the defeat of a Romania found in the opposing camp, Bulgaria also claimed North Dobrogea as a reward, i.e. a common border with Romania exclusively on the Danube. The declaration of war was submitted only to Serbia, given the fact that Romania was neutral. The situation could not but be an additional argument in favour of ententophiles in Romania. On the other hand, Russia will intensify her actions in order to force Romania into the war on the side of the Entente, even going to certain concessions during the negotiations, while regarding Bulgaria, it will give up any courtesies. Russia's efforts to get Romania into the war on its side have continued also on the pages of the Russian press.

The approach to the Transylvanian matter in the Russian press aims at the readers' emotional involvement into the drama of the Transylvanian Romanians. The issue of November 10, 1915 of the newspaper Our Messenger, referring to the information published in the Romanian newspaper Epoca, reports more compassionately about the Romanians' persecutions in Transylvania:

\footnotetext{
"Arrests and violence against the innocent inhabitants of this province take place every day. The gendarmes swear and beat the priests; they deprive the inhabitants of their goods. If the Romanian government does not want to help the Romanians who are suffering under the Hungarian yoke, let the people, our fellows, come to stop the crimes committed by the Hungarians." (Наш вестник, 1915, No. 94, р. 7)
}

On the mood of the Romanian people, the same newspaper tells us in its issue of November 14,1915 , bringing as an argument the confessions of the poet Octavian Goga, who took refuge from Transylvania to laşi, as well as the "long applauded" speech of Take Ionescu at a rally in laşi about the horrors of the Hungarians:

\begin{abstract}
"The Romanian Army against the Quadruple Agreement with the Austro-Germans? You have to be crazy or indiscriminate to imagine something like that. I consider it necessary to say that within this context any Romanian will feel free from any obligation and oath. The honour of the nation is above all constitutions. Any human institutions [...] The national honour would order us in this case to say "With the Germans? No. It is not possible!" (Наш вестник, 1915, No. 96, р. 3).
\end{abstract}

In the November 19 issue of the same newspaper, we may find an article about the situation in the Balkans, in which the author was ascertaining that:

"Romania seeks the unification of all Romanians within the borders of a Romanian unitary state. Romania aims to become Great. National interests draw it in the opposite direction to the Central Powers, which the figures speak of. Out of 13 million Romanians, only 7.5 million live within the national state, the remaining 5.5 million are distributed as follows: about 1 million in Bessarabia and over 4.5 million in Transylvania and Bukovina. In this way, almost half of the Romanian people in Austria-Hungary long for a nationally independent life." (Наш вестник, 1915, No. 98, p. 5)

In the same vein, the November 20th, 1915 issue of Petrograd Military District's newspaper, informs its readers that at the opening of the Romanian parliament on November 15, 1915, King Ferdinand's speech was interrupted by opposition shouts, "Down with the Hungarians! Down with the Germans! Leadus to Transylvania!" (Солдатский 1915, No. 121, p. 3). The news paper Our Messenger also reported on November 21, 1915 about the opening of the works of the 
Romanian parliament. It was emphasized that on this occasion, the parliamentary opposition organized a grandiose demonstration, and the king was greeted with the slogan "Down with the government! Long live Transylvania and Bukovina!” (Наш вестник, 1915, No. 99, р. 2).

The post-war fate of the Romanian provinces under the Austro-Hungarian rule will be the main topic of the articles referring to Romania in the Russian military pressalso in the first half of 1916. The Messenger of the 10th Army published in its pages on January 23, 1916 an analysis of Romania's positions to join the war, signed with the initials N.V.Criticizing Romania's in decision, the author wonders what Romania would gain if it had sided with Germanyand Austria:

\begin{abstract}
"Transylvania will not be given to it, because it would be a fatal blow for Hungary; compensations in the Balkan Peninsula on behalf of Serbia, Montenegro and Albania are not possible, as Romania is geographically separated from these territories by Bulgaria; cessions in the northern Bulgaria are also not possible, because even now Bulgarians cannot forget the loss of a part of Dobrudja. There remains only Bessarabia, which the Germans propose to Romania and which is still to be conquered, but just over a million inhabitants live in this province, while under the Hungarian yoke in Transylvania there are about 5 million Romanians, not to mention the fact that for Romania it is not timely to have an eternal enemy such as the powerful Russia, for a relatively small gain." (Вестник, 1916, No. 401, p. 2)
\end{abstract}

The Russian press is increasingly insisting on Bulgaria's aggressive plans against her northern neighbour, possibly in order to push Romania into the war on the side of the Entente. The issue of February 16, 1916 will threateningly state that "for some time now the Germans and Bulgarians have been building numerous fortifications near the Romanian border in Dobru dja, by the work of about 1,000 prisoners". The March 7 issue took, in the same style, information published by the Romanian newspaper "Acţiunea", which stated that in order to lift the spirits of the soldiers, the Bulgarian authorities shared geographical maps, marking the boundaries of the planned conquests, including Dobrudja, Thessaloniki, Serbia and Albania. Such maps we re sold freely in shops in conquered Macedonia. It was noted that the Romanian newspaper expressed its deep dismay at the respective disposition of the Bulgarian authorities. The newspaper "Aç̧iunea" was the official press organ of the Romanian Democratic Conservative Party, which together with the conservative group of N. Filipescu, was the organizer of the great campaigns of the country for entering the war on the side of Entente during the period of neutrality.

On the other hand, the newspaper Russian Invalid wrote on March 15, 1916 about the open letter, placed on the pages of the newspaper Adevărul of March 1, addressed to the Romanian Minister of War, but without mentioning the signers:

"In Transylvania, our brothers are groaning under the yoke of the Hungarian barbarians. They had long been looking at Romania and had expected for help, but they did not receive it. Thousands of our brothers die to defend foreign interests. Many, not resisting the Austro-Hungarian regime, fled to Romania. The Romanian government has to enlist refugees into the army. They will be happy to defend their true homeland - Romania with their own breasts - and will fight against their secular oppressors - the Hungarians. We hope that the war ministry will not refuse to give the permission to the Romanian refugees to show their love for Romania and will allow them to enlist in the ranks of the brave Romanian army." (Русский инвалид, 1916, No. 72, p. 5)

The March 27, 1916 issue of the same newspaper referred to an article published in the March 15 issue of the newspaper Adevărul:

"There has long been an irreconcilable hostility between Romania and Hungary, which has now turned into hatred. Romania cannot forget that the Hungarians keep Transylvania and Erdély (sic!) 
инвалид, 1916, No. 83, p. 5)

These accents in the Russian press were a clear indicator of the rough negotiations with the Entente, which was also perceived by the opposing side. The Russian press reflected this more eagerly. Thus, the Messenger of the 10th Army reported on April 18, 1916 that:

\begin{abstract}
"According to information from Switzerland, articles directed against Romania began to be published in the Hungarian press, and the Hungarian authorities introduced a regime of terror against the class of the Romanian intellectuals. The prominent political leaders in Transylvania were imprisoned; the main Romanian newspapers were closed. The number of refugees is daily increasing. According to the information from Bucharest, the last circumstances will not remain without influence on the decision of the Romanian government." (Вестник, 1916, No. 470, р. 2)
\end{abstract}

On July 14, 1916, the same newspaper wrote similarly that:

\begin{abstract}
"Transylvanian Romanians are waiting for Romania to enter the war in order to revolt. Aware of these moods, the Hungarians resort to repressions. [...] Romanian soldiers were forbidden to speak Romanian, the punishment being as in the case of prisoners of war by hanging. Two people have been sentenced to death recently. There are many desertions: 12,000 fled at the same time, and in total more than 50,000 deserted to Romania. Brătianu's policy of expectation is harshly criticized by the Austrian Romanians and is considered a tragedy for Transylvania, plundered by the Hungarians. It is hoped that the increase in the number of desertions will force Bucharest cabinet to go to war." (Вестник, 1916, No. 574, p. 2)
\end{abstract}

The newspaper Our Messenger shared an article of the Swiss periodical Neue Züriecher Zeitung. Its author drew attention to the fact that there were no less than 600 thousand Romanian soldiers in the Austrian army, that is the same number that was able to line up Romania, and stressed that:

\footnotetext{
"There is no doubt that the Austrian Romanians are looking forward to Romania's joining the war, and the Austrian Romanian soldiers, even if they will not openly disobey the Austrians, will in any case be an even more insecure element in the army than before. In their thoughts, they will always know that their brothers are fighting for the liberation of Transylvania." (Наш вестник, 1916, No. 197, pp. 2-3)
}

Despite these obvious developments, which seriously tipped the scales towards an alliance with the Entente, Romania's joining the war was not yet ready. This was due to the fact that the negotiations carried out by the Prime Minister Ion I.C. Brătianu and the leaders of the Triple Entente aimed at a firm recognition of Romania's rights over the territories inhabited by the Romanians in the Austro-Hungarian Empire, by virtue of the sad experience of 1878. But the position displayed towards Romania in the Russian press on the issue of Transylvania, Banat and Bukovina continued to be conciliatory, in order to hide this fact.

The Romanian government finally signed the treaty with the Entente nations on August 4/17, 1916, and on August 14/27, 1916 the Crown Council was convened, to formally express on the Romanian attitude towards the world conflagration and the achievement of the secular Romanian political-national ideal. On the evening of the same day, Romania declared war against the Austro-Hungarian Empire. The Russian newspapers provided a large space to announce and analyse Romania's entry into the war. The author of one of the articles of August 17/30 1916 issue of the Russian Invalid characterized the Romanian state officials as "very prudent and cautious, carefully defending the country's interests" (Русский инвалид, 1916, No. 219, p. 2). 


\section{Russian press on the territorial claims of allied Romania}

The Romanian decision to ally with the Entente, offered the Russian press a huge propaganda material. It will focus firstly on the reports about the enthusiasm of the population regarding both the decision to take the side of the Entente, and the warm welcome of the Russian armies deployed on the Romanian territory. For example, the newspaper Russian Invalid of August 18/31, 1916 appreciated that "due to its excellent strategic position on the banks of the Danube and its solid river fleet, Romania will be able to achieve a certain success in this theatre of war" (Русский инвалид, 1916, No. 220, p. 5). At the same time, the newspaper stated that the Russian armies, which passed through the Romanian territory, were greeted by the population with high admiration and enthusiasm: "Romanians everywhere show a feeling of hot sympathy for the Russian army and ask for the Russian national anthem to be performed" (Русский инвалид, 1916, No. 220, р. 5). Similar self-praises can be found also in the next issue of the same newspaper (Русский инвалид, 1916, №. 221, pp. 5-6). A large space is given by the Russian press to the analysis of the military potential of the new ally and to the appreciation of his past military successes (Разведчик, 1916, №. 1347, р. 550).

At the same time, the Russian press continued for a while to "mourn" the fate of the Romanians in Transylvania. Thus, the September 8, 1916 issue of the newspaper Our Messenger reports on the offensive of the Romanian armies in Transylvania. It was stated that:

\footnotetext{
"Everywhere they were greeted by empty localities, houses and shops. Romanian priests and teachers were arrested by Hungarians and sent inside the country. The mother of the famous poet and writer Octavian Goga was arrested in Transylvania and accompanied by gendarmes, and now shares the fate of other Romanians who had relatives in the Romanian army." (Наш вестник, 1916, No. 224, pp. 4-5)
}

The Messenger of the 10th Army informed that the retreating Hungarian army was burning the houses of the Transylvanian Romanians, while those of the Hungarians and Saxons were left untouched (Вестник, 1916, No. 638, p. 2). Gradually, the relating on the issue of Transylvania, Bukovina and Banat in the Russian press is reduced to reviewing only the state of military operations.

The only noticeable exception is the September 28, 1916 issue of the Russian Invalid newspaper, which included a report on the brochure "Current Romania and Its National Goals" signed by G.I. Kapchev, which had been published "a few days ago." The author of the article stated that by reading this brochure "it becomes clear the attitude of our new ally towards Austria, Hungary, Russia and Germany. Shortly but clearly the significance for Romania is shown, not only of Transylvania, which is already known, but also of Bukovina, as well as part of Banat which it claims." The author underlines that the brochure also includes a map with the territories of the neighbouring states historically claimed by the Romanians, but avoids mentioning anything about Bessarabia (Русский инвалид, 1916, No. 259, p. 6). Instead, the emphasis will be placed on the correctness shown by Russia in its relations with Romania and the Romanians in Bukovina. In this regard, we mention that the press organ of the 10th Army emphasizes the decision of the Russian authorities to spread the Romanian language press in Bukovina, in order to counter the Austro-German propaganda among the Romanian-speaking inhabitants (Вестник, 1916, No. 724, р. 2).

The revolution of February 1917 and the growing influence of the Bolsheviks in Russia brought a new opportunity to discuss the territorial issues, including in the media. Even though there was no change in tone, the Russian press's voice in the following month was not very interested in propaganda, but rather revealed a more realistic attitude towards its military 
position, with notes of self-criticism. Thus, in the issue of 19 July / 1 August 1917 of the newspaper Army and Fleet of Free Russia, we find a highly critical article from the London's Times towards Russia and, at the same time, eulogistic towards Romania:

\begin{abstract}
"The only bright spot on the eastern front is Moldavia, where the Romanian army offers a noble example for its great ally, who is being defeated further north. It is no secret that the restored Romanian army is large and strong, that if it had not been for the paralysis of the Russian front, the Romanians would have gone on the offensive several weeks ago. Their offensive was to coincide with the Russian offensive in Galicia, which had such deplorable consequences. Although the Russians are retreating, the Romanians continue to advance, resurrecting the reputation for steadfastness that their ancestors won at Pleven. [...] Although the chances of expelling the enemy are now gone, we must pay tribute to the valour of the Romanians that encourages them to continue their offensive under such dire circumstances. The Russians were almost completely defeated. Therefore, we must give up the hope of an immediate restoration of the Russian front power, for it is too difficult to eliminate the results of the disobedience that was allowed for months." (Армия, 1917, No. 166, p. 1)
\end{abstract}

The focus of the Russian official press would rather be on the Bolsheviks' actions inside and outside Russia, than on the battles of Mărăşti, Mărăşeşti and Oituz, and on the supreme sacrifice paid by the Romanians to stop the Central Powers' offensive. Bolshevik propaganda was growing fast, and its danger will soon be acknowledged also by the Romanian authorities.

Following the deliberations during the secret meeting of the Central Executive Committee of the Soviets of October 3-5, 1917, which was also attended by delegates of the military organizations from the front and representatives of the Russian Council of Peasant Deputies, a resolution was adopted, the provisions of which, M.I. Skobelev, one of the Russian revolutionary leaders, was empowered to proclaim at the upcoming Allied conference in Paris. Namely it demanded "peaceful conditions without annexes and war contributions based on the self-determination of the peoples". Poland, Latvia, Lithuania, Turkish Armenia, AlsaceLorraine, but also Dobrudja were specifically targeted. In reply, on the pages of the new Russian War Ministry's newspaper, we find an extremely interesting article, representing the discussions on defence issues within the Provisional Council of the Republic, an adviso ry body of the provisional government. At the meeting of October 18, 1917, the representative of the Party of Cadets, P.N. Milyukov, the former Russian foreign minister, gave an extensive speech, in which he also referred to the Dobrudja issue. Criticizing harshly the positions of the left parties, he stated that "Russian revolutionary democracy insists on the full self-determination of Dobrudja, that is, it cuts Romania off the sea and says nothing about Transylvania. It turns out that the Russian radicals do not have the courage to go beyond the borders of the Central Powers. Russian radicalism considers only Russia's interests and behaves absolutely nonchalantly towards the interests of our allies" (Армия, 1917, No. 240, р. 3).

One of the following issues of the same newspaper included Romania's reactions to Skobelev's "mandate". The reply of Professor N. lorga is presented, who expressed his regret that the authors of the "mandate" did not take into account the conditions in which Romania received Dobrudja in 1878, namely the return to Russia of the three counties in southern Bessarabia. The question is also asked why the principle of self-determination is not put in relation to Transylvania and Bessarabia" (Армия, 1917, No. 243, p. 1). The publication of these ideas denotes an intransigent position of the Petrograd authorities on the Dobrudja issue at that time - the territory was to remain as part of Romania. Incidentally, on October 16, Foreign Minister M.I. Tereshchenko, in a speech to the Provisional Council of the Republic, said that "Skobelev's mandate" represents many disadvantages for Russia's interests, and the Russian 
government delegation should act in Paris as a unitary team, so that Skobelev's voicing of a separate statement is unacceptable (Орлов, 2011, p. 224).

\section{Russian press on the territorial claims of Romania after the Bolshevik Revolution}

The Bolshevik revolution of October 25 / November 7, 1917 in Russia will cause a total collapse on the Eastern front. As a result of Lenin's will, Germany and Bolshevik Russia will conclude in Brest Litovsk an agreement on ceasefire from November 24 / December 7 to December 4 / 17, 1917, which will open the parley for an Armistice and for the Peace Treaty. At the same time, General D.G. Scherbachev, the commander of the Russian armies in Romania, denie d to obey the Bolshevik government, but instead accepted to support the Ukrainian Rada and brought his armies into the obedience of the Ukrainian People Republic, keeping his position. He initiated separate talks for an armistice, having to struggle with the Bolshevik elements with in the army. This will oblige Romania to take quick steps in the same direction, in order to avoid the obnoxious situation of facing alone the enemies on the Eastern front. Thus, on Nove mber 26 / December 9, 1917, with the mediation of general Scherbachev, Romania will sign in Focşani, an armistice with the Central Powers, which stipulated that the Russian and GermanAustro-Hungarian troops temporarily cease hostilities on the Romanian front, "until the issue of war or peace is decided by the Constituent Assembly of Russia" (Рабочая, 1918, No. 8, p. 2).

Meanwhile, the Democratic Republic of Moldova is formed within the territory of Bessarabia, which opposes the new power established in Petrograd. As a response, Bolsheviks began the military operations for the annexation of the province, contrary to the expressed will of its population for self-determination. We may call it an attempt for the second annexation of the province (after the annexation of 1812 to the Russian Empire), because the Bolshevik elements, who were waging for establishing the Soviet power in Bessarabia, were mostly former soldiers of the Russian armies from the Romanian front, with no relation to Bessarabia. The dismemberment of the Russian Empire as the result of the Bolshevik coup meant Soviet Russia did not have any rights on the newly constituted republics within the former borders, which were occupied by the Russian autocracy during the $18^{\text {th }}$ and $19^{\text {th }}$ centuries, as the result of military campaigns. Not to mention, the Bolsheviks were those who propagated the idea of national self-determination. After the elections of Sfatul Jării (the Country Council), and opening of its debates in Chişinău / Kishinev on November 21 (December 4), 1917, the Bessarabian Assembly attempted to adopt some measures to protect the province from the events occurring in the Russian central regions. On December 2/15, 1917, in Chişinău, Sfatul Jării proclaimed the autonomy of the Moldavian Democratic Republic. At first, both the Petrograd Soviet and the Council of People's Commissars acknowledged the new Moldavian Republic, its government and Assembly - Sfatul Jării. But after the Bessarabian Assembly appealed on December 8/21, to Romanian government for military assistance to fight against Bolsheviks' attempts to capture the power in the province and annex it to Soviet Russia, its attitude towards this body will radically change (Mitrasca, 2002, pp.33-34).

On January 11/24, 1918, with the support of the Romanian armies, the Country Council declared the independence of the Democratic Republic of Moldova. As a reply, the press organ of the People Commissariat for Military and Maritime Affairs, will publish the decision of the Soviet of People Commissars of 13/26 January 1918, under the title "The fight against the Romanian oligarchy and the declaration of General Scherbachev as an enemy of the people". This document stated that "the Romanian monarchy tries to save itself, as well as its landlords and bankers, by occupying Bessarabia and turning it into a bastion against the strong current 
of the Russian revolution" (Армия 1918, No. 12, р. 4). It is for the first time when the proble m of Bessarabia in relation to Romania is posed by the new Russian authorities, and a direct military confrontation will be shortly reached. As the military situation of Romania had become critical, and the defeat before the Central Powers seemed imminent, Bessarabia became very important, as it represented the rear of its Army, and the presence of hostile Bolsheviks was not acceptable at all.

Because of the fear of Bolsheviks, on 27 March / 9 April 1918, Sfatul Jării voted for the union of Bessarabia with the Kingdom of Romania. Russian Deputy Commissar for Foreign Affairs Gheorghi Chicherin sent a note to the Romanian authorities to protest "the annexation" of Bessarabia, accusing them of not respecting the will of the masses and of acting in the interests of the landowners. In reality, as the historian Marcel Mitrasca emphasizes, the landowners were actually those who were permanently fighting against the Union (Mitrasca, 2002, p. 39). The protest of the Foreign Affairs Commissariat to Romanian Prime Minister Marghiloman's announcement regarding the unification of Bessarabia with Romania was distributed in extenso or partially in most Bolshevik newspapers, under the generic title "Concerning the annexation of Bessarabia to the Kingdom of Romania." In the telegram, the re are several statements, including that Sfatul Jării was representing only the interests of large landowners "adepts of exploiting the people" and that this action "has no importance from the point of view of international law", and that "violent separation of Bessarabia from Russia breaks the fraternal unity of the working masses from this territory" (Русский солдат, 1918, No. 186, pp. 7-8). This proves that the Soviet Government did not have any valid arguments against the procedure the union was made, other than ideological.

Bessarabia actually was very important for the Bolsheviks from a strategic point of view, as it was ensuring access to the Danube and the Balkans, and could allow them to export Soviet revolutions abroad, but it was also seen as a buffer area, to protect Odessa and the Ukrainian granaries in case of war. At the same time, it could also ensure large food supplies to Soviet armies during the confrontations against the White Armies. Actually, in the Bolshevik press, we find the protest of 20 April 1918 of the Ukrainian Rada, a declared enemy of the Bolshevik government, against the union of Bessarabia with Romania, dispatched to Vienna and Berlin (Рабочая, 1918, No. 69, p. 4). On the on hand, this shows that any arguments were viable for the Bolsheviks, when that corresponded to their interest, and, on the other hand, that Bessarabia was similarly important strategically and economically for both Red and White armies.

Nevertheless, both the Central Powers and the Entente Powers approved the Union. In the issue of Красная Армия of 4 May 1918, a communiqué that the Soviet of People Commissaries received, the note of the German ambassador on the union of Bessarabia with Romania, which stated that Germany and Austria agreed with it is published. Still it decided not to take it in consideration, "as the people of Bessarabia were not polled" (Красная Армия, 1918, No. 3, p. 4). The acceptance of the Central Powers on the Union of Bessarabia convinced Romania to accept the unfavourable clauses of the Peace Treaty with the Central Powers and to sign it on the $7^{\text {th }}$ of May. The Bolshevik press started instead to include a special rubric describing the situation in "Occupied Bessarabia" in dramatic tones, signalling "the violence exerted by the Romanian authorities to the civil population" of the province, "the execution of innocent people", the departure over the Dniester of all those who expressed disagreement with the union (Красная Армия, 1918, No. 8, p. 2), etc. These kinds of accusations will periodically appear onward in the Soviet press. 
Following the change in the situation on the war fronts, and defeat of Austria-Hungary on November 3, 1918, the Romanians and Ukrainians in the Duchy of Bukovina simultaneously demanded the union of the territories where they were the majority, with the Kingdom of Romania and, respectively, with a newly proclaimed West Ukrainian People's Republic. On October 29 / November 11, at the request of the Romanian National Council, the Romanian Armies entered Czernowitz / Cernăuţi. Within this context, the Russian newspaper Armed people reported that information had been collected from Vienna, according to which Bukovina was "occupied by an army consisting of Austrian Romanians. The population is in turmoil” (Вооруженный, 1918, No. 110, p. 1). The same information, almost literally, can be found in other Bolshevik newspapers (Ржевская, 1918, No. 292, р. 2). Actually, the union of the largest part of Bukovina with Romania was perceived very negatively by the new Russian authorities. The newspaper Armed People continued in the same manner in the December 3, 1918 issue:

\footnotetext{
"On the southern front, the allies intend to use the Romanian military forces. The Allies intend to generously reward the Romanian imperialists on behalf of the defeated states. On behalf of Russia, Romania was promised Bessarabia, on behalf of Hungary, Transylvania, on behalf of Austria, Bukovina, in the Balkan Peninsula, Dobrudja. The Romanian imperialists are ready to serve the allies with lust. Instead, the Allies ordered Romania to occupy southern Russia with its army and to quell the revolution in Ukraine." (Вооруженный, 1918, №. 115, p. 1)
}

After the unification of Bukovina, the National Assembly of the Romanians from Transylvania and Hungary agreed and decided the unification of Transylvania and Banat with Romania in Alba lulia on 18 November / December 1, 1918. Apparently, the unification of all the Romanian territories has been accomplished successfully. But the fight for defending the union was only at the beginning.

The Russian Bolsheviks' military actions against Romania increased substantially in the following months. The operation to "liberate" Bessarabia began according to the classic scheme for the Bolsheviks: a rebellion of Bolshevik groups in strategic localities, which would attract the need for military "assistance" from Soviet Russia. In this regard, "military revolutionary committees" were formed in Bolgrad, Reni, Cahul, Ismail, Bender and Akkerman, as well as a "central military revolutionary committee" in Chişinău (Ponomariov, 2012, p. 330). The Bolshevik press, in turn, will trumpet about the successes of the "general uprising throughout Bessarabia, directed against the Romanians" and the repressive actions of the "occupation authorities" (Деревенская, 1919, №. 33, p. 1; No. 47, p. 1). At the same time, the information shared by the Bolshevik newspapers of all ranks, and also in those abroad, obedient to the Third International, aimed to promote the idea that the military actions were actually rebellions of the Bessarabian workers and peasants, who were "deeply dissatisfied with the Romanian occupation". The purpose was to create the impression that Romania did not control Bessarabia and that the province would be a permanent point of tension, by virtue of which the international recognition of the Act of Union of March 27 / 9 April 1918 was not opportune.

On February 1, 1919, the head of the Romanian delegation, Ion I.C. Brătianu, made before the Peace Conference the first exposition of Romania's rights over Bessarabia, and other re cently united Romanian territories, in the memorandum entitled Romania in Front of the Peace Conference and Its Territorial Claims. He demonstrated that the decision of the Bessarabian Romanians to unite with Romania was taken in accordance with the principle of selfdetermination, and the conference was called to recognize de jure the new territorial status of the country. One week later, on February 8,1919 , the first debate on the issue of Bessarabia 
took place in the Committee on Romanian and Yugoslav Affairs, which ruled "temporarily in favour of reuniting Bessarabia with Romania". In his turn, the representative of France, Jules Laroche, highlighted the historical and ethnographic arguments that were the basis for recognizing the union of Bessarabia with Romania, emphasizing that in 1812, this province had been forcibly attached to the tsarist empire (Constantin, 2017, p. 86).

The Bolsheviks will respond by spreading threats in their newspapers. The February 11, 1919 issue of The Countryside Commune reported that the president of Ukraine's workers' and peasants' interim government, C. Rakovski, had addressed to the president of the peace conference, Georges Clemenceau, protesting against the "imperial policy of the Romanian landlord government, which officially proposed the conference to recognize the unification of Bessarabia with Romania", threatening that Bolshevik Russia "will not stop using any means to liberate the workers and peasants of Bessarabia from the yoke of the Romanian bourge oisie" (Деревенская, 1919, №. 32, р. 2).

At the same time, Romania had to face another challenge, the Hungarian Soviet Republic. The latter appeared mostly as a result of the Hungarian people refusing their new borders, and especially the cession of Transylvania to Romania. The new Hungarian government, like the previous one, rejected the allies' proposals regarding the demarcation line, and began a war against Romania in order to prevent her from advancing to the new demarcation line and to return the whole of Transylvania on April 16, 1919. The Hungarian offensive was however stopped, and by April 18, the Romanian counter-offensive managed to break the Hungarian front (Mărdărescu, 1922, pp. 48-49). The first successes of the Romanian Army against the Hungarian Soviet Army triggered a massive informational campaign against Romania, which included all the types of propaganda such as subversive propaganda, defamatory propagan da and war propaganda (Деревенская, 1919, №. 90, p. 1).

In the midst of the Hungarian-Romanian War, in June 1919, the issue of borders in Banat is being intensely discussed in the Council of Foreign Ministers in Paris, important concessions from Romania being proposed, without its representatives being consulted. The Bolshevik press will find an opportunity to "pity" Romania, fuelling hopes for the involvement of the Romanians in a new war for Banat (Известия, 1919, No. 136, р. 1).

\footnotetext{
"The Romanian imperialist press has sounded the alarm regarding the decisions of the peace conference, to cede Banat to Serbia. The bourgeois classes shout about the violation of fairness." (Известия, 1919, No. 142, р. 1)
}

The Russian Bolshevik press will insist on the outbreak of an armed conflict between Serbia and Romania. The situation around Banat strengthens Bolshevik goals to continue the offensive in Bessarabia, despite the difficulties they were facing in Ukraine. The newspaper Petrograd Izvestia wrote that because of the Banat issue "[c]lashes take place between Romanian and Serbian military units. In Romania, it is considered that the declaration of war in Yugoslavia is inevitable" (Известия, 1919, No. 136, р. 1).

In addition, the Bolshevik press will find in this situation an opportunity for propaganda on the issue of Bessarabia. Informing about the fact that in Bessarabia the Romanian government organized patriotic demonstrations in support of Banat, the newspaper Petrograd Izvestia will launch into slander:

"In the residence of the Costeşti commune, the peasants from the surroundings were gathered, being surrounded by a detachment of mounted and machine-gun gendarmes. The prefect of Chişinău County read them a resolution, which included the request to address the International Conference, to acknowledge the right of Romania to unite with Banat. The peasants were warned 
that if they refused, they would be executed. The resolution was, of course, signed." (Известия, 1919 , No. 142 , p. 1)

Despite these expectations, a consensus was reached on the Banat issue, and on July 11, 1919 the Allied council ordered Marshal Ferdinand Foch to prepare a coordinated attack on the Soviet Hungary using Serbian, French and Romanian forces. On July 17, Hungarian leader Béla Kun ordered the start of the hostilities against Romania, "which refused to withdraw its army from 'Eastern Hungary'”. Petrograd newspaper Izvestia reported about the primary succe sse s of Hungary, which attacked the Romanian armies "in order to enter in the possession of the provinces, across the Tisza, distributed according to the note of the president of Paris peace conference, in our favour" (Известия, 1919, №. 167, р. 2). But on July 24, the Romanian army launched a counterattack, returning its strategic initiative, and on the night between July 29 and 30, they forced the Tisza. By August 3, the Hungarian Red Army was surrounded and had to surrender. Thus, on August 4, 1919 the Romanian army entered Budapest under the command of General Gheorghe Mărdărescu. Béla Kun resigned and the Communist regime was ousted (Bodale, 2004, pp. 102-103).

The following day, Russian Telegraph Agency's communiqué distributed to Soviet press stated that:

"Ungarischen Post considers that the government of Segedin (Szeged) intends to propose the Hungarian crown to the king Ferdinand of Romania. It is officially reported that King Ferdinand went on an urgent visit to Budapest." (Петроградская Правда, 1919, No. 181, p. 2)

Bolshevik newspapers will actually favour the rumours that the Hungarian crown will be proposed to the Romanian king Ferdinand, and consequently propagated the idea of Hungary's annexation to Romania (Известия, 1919, No. 182, р. 1). They kept feeding information of this kind to their readers for several months in row. In mid-November, for example, the newspaper Military Pravda published an article entitled Seven Candidates for a Crown, suggesting that one of the candidates for the Hungarian crown was from the Romanian royal family (Боевая Правда, 1919, No.64, p. 4).

Romanian diplomacy succeeded to include the cession of Transylvania to Romania, and the international recognition of the Act of Union of December 1, 1918 from Alba lulia in the Treaty of Trianon of June 4, 1920. The Soviet press has paid little attention to this aspect, continuing instead to publish defamatory articles against Romania, incriminating the fall of the Hungarian Soviet Republic. After a long and complicated procrastination, the union of Bessarabia with Romania was also acknowledged de jure by the Treaty signed in Paris, on October 28, 1920, between Great Britain, France, Italy and Japan, on the one hand, and Romania, on the other. This treaty acknowledged the legitimacy of the union of Bessarabia with its motherland and the Romanian sovereignty over the territory between the Prut, the Dniester, and the Black Sea. The Soviet protest was not considered by the Great Powers, but Russia's absence from the Conference was perceived as a "vulnerable aspect" of the October 28, 1920 treaty.

\section{CONCLUSIONS}

The analysis of the Russian press allows us to conclude that in the information war against the Central Powers, Russia resorted to propaganda tools and techniques, in order to denigrate the image of the enemy at its maximum. Regarding Romania, its media discourse will be centred mostly on the problem of Transylvania. A commonly practiced procedure was to take over 
some articles of the Romanian press, some of which were even committed to be published at the "order" of the Russian Information Bureau. After Romania entered the war on the side of the Entente, the attention of the Russian military press towards the Romanian territories practically disappeared, but reappeared very intensely towards the end of the war, with the two Russian revolutions in 1917. The dismemberment of the Russian Empire brings fore into the relation of the Soviet Russia and Romania the problem of Bessarabia, which chooses to follow its own political path, under the protection of the latter. The Russian press, which is undergoing a series of radical transformations within this context, is once again tasked with supporting the diplomatic dispute between the two states in the media.

After the union of Bessarabia with Romania, the Russian press, regardless of its political colour, will have the role of spokesperson in supporting the recovery of Bessarabia by new Russia, both militarily and diplomatically. The published articles will have an obvious propagandistic character, resorting to various techniques of manipulation and introducing the facts in order to denigrate Romania, without bringing clear arguments regarding the claims towards the territory between the Prut and the Dniester. The union of other territories with Romania will concern lesser the Russian press, but the same attitude of disapproval and censure towards Romania will be shown.

\section{REFERENCES}

\section{PRIMARY SOURCES}

AРМИЯ [ARMIJA] (1917). Армия и флот свободной России [Army and Navy of Free Russia]. Петроград: Военная типография [Petrograd: Military Printing House].

AРМИЯ [ARMIJA] (1918). Армия и флот рабочей и крестьянской России [Army and Navy of Workers' and Peasants' Russia]. Петроград: Типография Совета Народных Комиссаров по военным делам [Petrograd: Printing House of the Council of People's Commissars for Military Affairs].

БОЕВАЯ ПРАВДА [ВОEVAJA PRAVDA] (1919). Боевая Правда [Military Pravda]. Петроград: 14-я Государственная Типография [Petrograd: 14th State Printing House].

BECTHИК [VESTNIK] (1915). Вестник Х армии [Messenger of the 10th Army]. Типография Штаба Х-й армий [Printing House of the Headquarters of the 10th Army].

ВЕСТнИк [VESTNIK] (1916). Вестник Х армии [Messenger of the 10th Army]. Типография Штаба Х-й армий [Printing House of the Headquarters of the 10th Army].

ВOOРУЖЕНнЫЙ [VOORUZHENNYJ] (1918). Вооруженный народ [Armed People]. Петроград: Типография газеты «Красная Армия» [Petrograd: Printing House of the Newspaper "Red Army"].

ДЕРЕВЕНСКАЯ [DEREVENSKAJA] (1919). Деревенская коммуна [Countryside Commune]. Петроград: Типография Петроградского Совета Рабочих и Красноармейских Депутатов [Petrograd: Printing House of the Petrograd Soviet of Workers and Red Army Deputies].

ИЗВЕСТИЯ [IZVESTIJA] (1919). Известия Петроградского Совета Рабочих и красноармейских депутатов [Izvestia of the Petrograd Soviet of Workers' and Red Army Deputies]. Петроград: 4-я Государственная Типография [Petrograd: 4th State Printing House].

ИЗВЕСТИЯ [IZVESTIJA] (1920). Известия Петроградского Совета Рабочих и красноармейских депутатов [Izvestia of the Petrograd Soviet of Workers' and Red Army Deputies]. Петроград: 4-я Государственная Типография [Petrograd: 4th State Printing House].

КРАСНАЯ АРМИЯ [KRASNAJA ARMIJA] (1918). Красная Армия [Red Army]. Петроград: Типография Петроградской Трудовой коммуны [Petrograd: Printing House of the Petrograd Labour Commune].

НАШ ВЕСTHИК [NASH VESTNIK] (1915). Наш вестник [Our Messenger]. Петроград: Штаб главнокомандующего армиями северо-западного фронта [Petrograd: Headquarters of the Commander-in-chief of the Armies of the Northwestern Front]. 
ПЕТРОГРАДСКАЯ ПРАВДА [PETROGRADSKAJA PRAVDA] (1919). Петроградская Правда [Petrograd Pravda]. Петроград: 14-я Государственная Типография [Petrograd: 14th State Printing House].

РАБОчАЯ [RABOCHAJA] (1918). Рабочая и крестьянская Красная Армия и Флот [Workers' and Peasants' Red Army and Navy]. Петроград: Типография Совета Народных Комиссаров по военным делам [Petrograd: Printing House of the Council of People's Commissars for Military Affairs].

РАЗВЕДЧИК [RAZVEDCHIK] (1916). Разведчик. Журнал военный и литературный [Scout. Military and Literary Magazine]. Петроград: Издание Т-ва «В.А. Березовский».

РЖЕВСКАЯ [RZHEVSKAJA] (1918). Ржевская Правда [Rzhev Pravda]. Ржев [Rzhev].

РУССКИЙ ИНВАЛИД [RUSSKIJ INVALID] (1914). Русский инвалид [Russian Invalid]. Петроград: Типография Главного Управления Уделов [Petrograd: Printing House of the Main Administration of Real Estates of the Royal Family].

РУССКИЙ ИНВАЛИД [RUSSKIJ INVALID] (1915). Русский инвалид [Russian Invalid]. Петроград: Типография Главного Управления Уделов [Petrograd: Printing House of the Main Administration of Real Estates of the Royal Family].

РУССКИЙ ИНВАЛИД [RUSSKIJ INVALID] (1916). Русский инвалид [Russian Invalid]. Петроград: Типография Главного Управления Уделов [Petrograd: Printing House of the Main Administration of Real Estates of the Royal Family].

РУССКИЙ СОЛДАТ [RUSSKIJ SOLDAT] (1918). Русский солдат-гражданин во Франции [Le Soldat-Citoyen Russe en France]. Paris: Union.

сОЛДАТСКИЙ [SOLDATSKIJ] (1915). Солдатский вестник Петроградского военного округа [Soldier's Messenger of the Petrograd Military District]. Петроград: Типография Императорской Николаевской военной академии [Petrograd: Printing House of the Imperial Nikolaev Military Academy].

\section{SECONDARY SOURCES}

BODALE, H. (2004). Armata română în Budapesta (1919-1920). Administraţia militară română şi percepţia socie tăţi maghiare [Romanian Army in Budapest (1919-1920). Romanian Military Administration and the Perception of the Hungarian Society]. Studia Universitatis Babeș-Bolyai, Studia Historia, 1, 101-121.

CONSTANTIN, I. (2017). Diplomaţia română în lupta pentru recunoaşterea internaţională a unirii Basarabiei cu Patria Mamă [Romanian Diplomacy in the Fight for the International Recognition of the Union of Bessarabia with the Motherland]. Revista de Istorie a Moldovei, 112(4), 83-101.

ISTORIA (1989). Istoria militară a poporului român [The Military History of the Romanian People]. Vol. V. București: Editura Militară.

MĂRDĂRESCU, G.D. (1922). Campania pentru desrobirea Ardealului şi ocuparea Budapestei [The Campaign for the Liberation of Transylvania and the Occupation of Budapest]. Bucureşti: Cartea Românească.

MITRASCA, M. (2002). Moldova: a Romanian Province under Russian Rule. Diplomatic History from the Archives of the Great Powers. New York: Algora Publishing.

PONOMARIOV, V. (2012). Consideraţii privind activitatea comunistă în Basarabia în anii 1918-1921 [Considerations regarding the Communist Activity in Bessarabia in 1918-1921]. Danubius, XXX, 327-350.

SPÂNU, A. (2012). Serviciul de Informaţii al României în Războiul de Întregire Naţională (1916-1920) [Romania's Intelligence Service in the War for the National Integration (1916-1920)]. Bucureşti: Editura Militară.

UNGUREANU, C. (2014). Bucovina în timpul Primului Război Mondial. Proiecte de dezmembrare teritorială [Bucovina during the First World War. Projects of Territorial Dismemberment]. Revista de istorie a Moldovei, 99(3), 120-138.

ВОЛКОВСКИЙ, Н.Л. [VOLKOVSKIJ, N.L.] (2003). История информационных войн [History of Informational Wars]. 4. 2. СПб.: Полигон [Part 2. SPb.: Polygon].

ОРлОВ, А.В. [ORLOV, A.V.] (2011). Внешняя политика и международные отношения России с середины ХІХ века до 1918 года [Foreign Policy and International Relations of Russia from the Middle of the 19th Century to 1918]. Санкт-Петербург: НИУ ИТМО [St. Petersburg: NRU ITMO]. 